WSRC-TR-2002-00070, Revision 0

\title{
Yield Stress and Physical Data Results for the Tank 19F Radioactive Mound Sample and Tank 19F Simulant Samples (U)
}

E. K. Hansen
T. L. Fellinger

Westinghouse Savannah River Company

Savannah River Site

Aiken, SC 29808

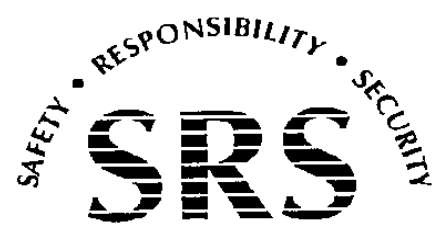

PREPARED FOR THE U.S. DEPARTMENT OF ENERGY UNDER CONTRACT NO. DE-AC09-96SR18500 
This document was prepared in conjunction with work accomplished under Contract No. DEAC09-96SR18500 with the U.S. Department of Energy.

\section{DISCLAIMER}

This report was prepared as an account of work sponsored by an agency of the United States Government. Neither the United States Government nor any agency thereof, nor any of their employees, makes any warranty, express or implied, or assumes any legal liability or responsibility for the accuracy, completeness, or usefulness of any information, apparatus, product or process disclosed, or represents that its use would not infringe privately owned rights. Reference herein to any specific commercial product, process or service by trade name, trademark, manufacturer, or otherwise does not necessarily constitute or imply its endorsement, recommendation, or favoring by the United States Government or any agency thereof. The views and opinions of authors expressed herein do not necessarily state or reflect those of the United States Government or any agency thereof.

This report has been reproduced directly from the best available copy.

Available for sale to the public, in paper, from: U.S. Department of Commerce, National Technical Information Service, 5285 Port Royal Road, Springfield, VA 22161

phone: (800) 553-6847

fax: (703) 605-6900

email: orders@ntis.fedworld.gov

online ordering: http://www.ntis.gov/support/index.html

Available electronically at http://www.osti.gov/bridge

Available for a processing fee to U.S. Department of Energy and its contractors, in paper, from: U.S. Department of Energy, Office of Scientific and Technical Information, P.O. Box 62, Oak Ridge, TN 37831-0062

phone: (865)576-8401

fax: (865)576-5728

email: reports@adonis.osti.gov 
WSRC-TR-2002-00070, Revision 0

Keywords: Tank 19F, Zeolite, Yield Stress, Rheology, and Settling Test

Retention: Permanent

\section{Yield Stress and Physical Data Results for the Tank 19F Radioactive Mound Sample and Tank 19F Simulant Samples (U)}

E. K. Hansen

T. L. Fellinger

Publication Date: February 11, 2002

Westinghouse Savannah River Company

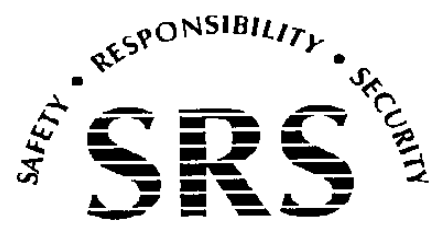


APPROVALS

Lem f felling

T. L. Fellinger, Co-Author, Immobilization Technology

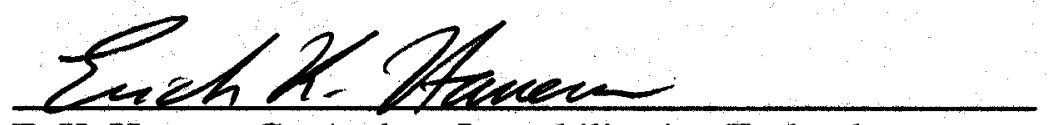

E. K. Hansen, Co-Author, Immobilization Technology

Llaind For pm

D. C. Koopman, Technical Reviewer

Shaven Limawa

S. L. Mara, Level 4 Manager

$\frac{\text { Q Avid a. Cum bey }}{\text { D. A. Crowley, Level } 4 \text { Manager }}$ $\frac{2 / 12 / 02}{\text { Date }}$

$\frac{2 / 11 / 02}{\text { Date }}$

$2 / 11 / 02$

Date

$2 / 1 / 102$

Date

$\frac{2 / 11 / 02}{\text { Date }}$ 
WSRC-TR-2002-00070

Page 5 of 26

\section{TABLE OF CONTENTS}

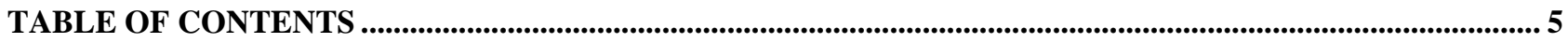

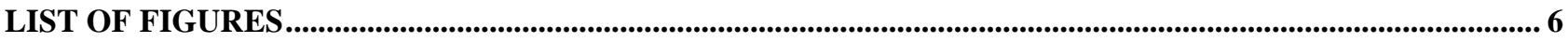

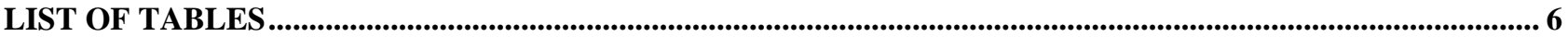

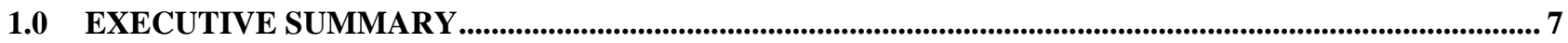

2.0 INTRODUCTION

3.0 SAMPLING AND RECEIPT OF THE RADIOACTIVE TANK 19F MOUND SAMPLE............................9

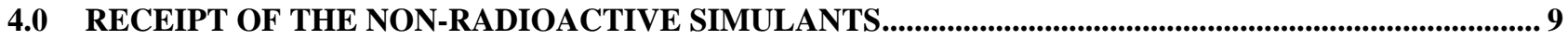

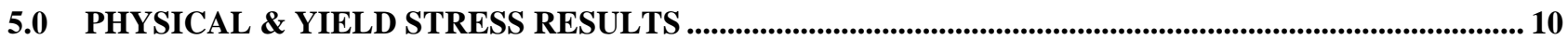

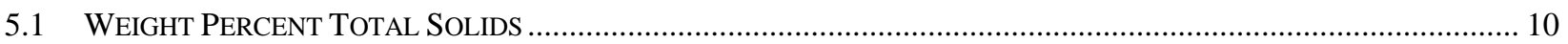

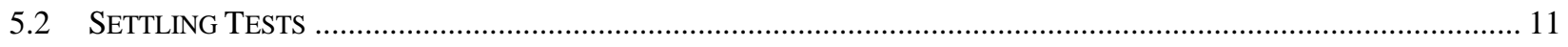

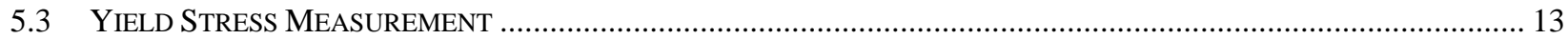

5.3.1 Method and Equipment to Perform Yield Stress Measurements ..................................................... 13

5.3.2 Yield Stress Measurement - Radioactive Tank 19F Sample............................................................. 17

5.3.2 Yield Stress Measurement - PNNL Simulants ................................................................................ 18

5.3.2 Density and wt. \% total solids for PNNL Simulants used for yield stress measurements ....................... 22

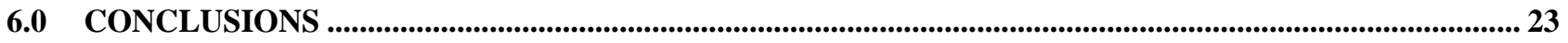

APPENDIX A: A \& M FACTORS - CALCULATED VALUES.............................................................................. 24

SHEAR RATE CONVERSION BETWEEN ANGULAR VELOCITY AND ROTATIONAL SPEED........................................... 24

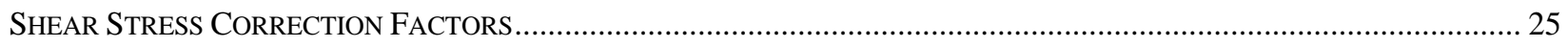

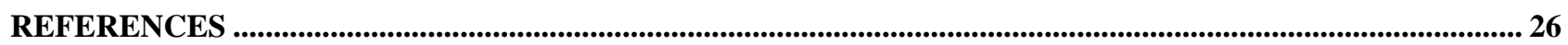


WSRC-TR-2002-00070

Page 6 of 26

\section{LIST OF FIGURES}

Figure 1: "As Received" Radioactive Tank 19F Mound Sample in the Shielded Cells

Figure 2: Radioactive Tank 19F Slurries Prepared at 6, 11, and 16 Weight Percent Total Solid

Slurries

Figure 3: PNNL Simulant Slurries at 16 wt. \% Total Solids Compared to the FL-22 Vane Rotor ................. 13

Figure 4: Vane Rotor Geometric Conditions For Measurement ................................................................. 14

Figure 5: Radioactive Tank 19F Sample Prior To and After the First Vane Measurement in the Shielded Cells 17

Figure 6: Radioactive Tank 19F Sample Prior To and After the Second Vane Measurement in the Shielded Cells (Next Day).... .17

Figure 7: Vane Measurements for Radioactive Tank 19F Sample ........................................................... 18

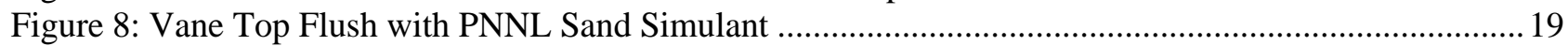

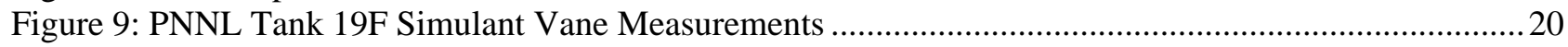

Figure 10: PNNL Zeolite Simulant Vane Measurements ................................................................2 21

Figure 11: PNNL Sand Simulant Vane Measurements............................................................................21

\section{LIST OF TABLES}

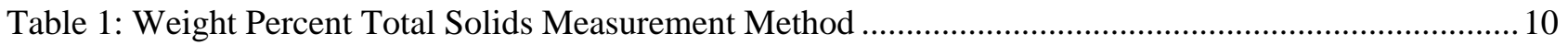

Table 2: Weight Percent Total Solids of As-Received Samples .............................................................. 11

Table 3: Masses Used to Make 6, 11 and 16 Weight Percent Total Solids Slurries ....................................... 12

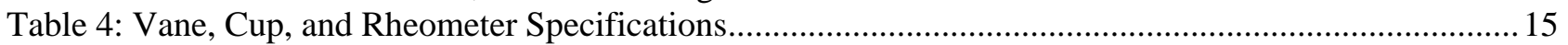

Table 5: A, M and Stress Correction Factors for the RV30/M5 and RS150 Rheometers............................... 16

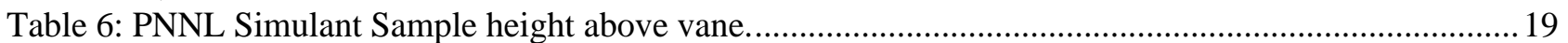

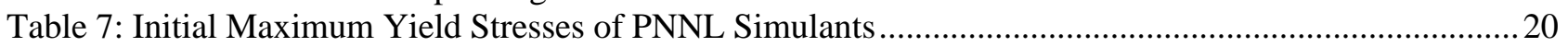

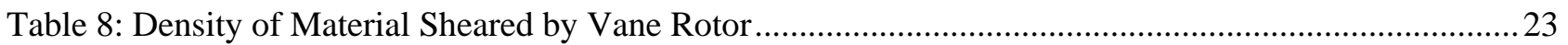


WSRC-TR-2002-00070

Page 7 of 26

\subsection{EXECUTIVE SUMMARY}

The purpose of this work was to characterize and compare the settling behavior of the radioactive Tank 19F mound sample and non-radioactive Pacific Northwest National Laboratory (PNNL) simulants at 6,11 and 16 weight percent total solids. The samples were to be characterized for their rheological properties as well. This work was in response to TTR: HLE-TTR-2001-038, Rev.2.

The radioactive Tank 19F sample and PNNL simulants settled very quickly and can be considered non-homogenous slurries due to this behavior. Rheological work was limited to yield stress measurements only, because these slurries were fast settling.

The radioactive Tank 19F sample and PNNL simulants exhibited about the same yield stress subject to about the same measurement conditions. Measured yield stresses ranged between 290 to 446 Pascal. Measurements were made using the vane method in slurries ranging from 53 to 74 weight percent total solids. This yield stress should be used with caution in hydrodynamic correlations or equations. 
WSRC-TR-2002-00070

Page 8 of 26

\subsection{INTRODUCTION}

The high level liquid waste, generated at Savannah River Site (SRS) during many years of producing nuclear materials for the USA, is stored in underground steel tanks as caustic slurries. A portion of this caustic slurry is currently being immobilized into a durable borosilicate glass by the Defense Waste Processing Facility (DWPF) for permanent geological disposal. The tank closure process is started, after the majority of the caustic slurry is removed from a tank. A characterization of the waste remaining in the tank is required to close a tank permanently. The data obtained from these characterizations will be used as the input for the groundwater transport models. These models are used to confirm the fate and transport of various species that remain in the tank.

Currently, Tank $19 \mathrm{~F}$ is undergoing the tank closure process. The remaining material in Tank $19 \mathrm{~F}$ is being transferred to Tank $18 \mathrm{~F}$. The material in Tank $18 \mathrm{~F}$ will eventually be transferred to Tank $7 \mathrm{~F}$ where it will become part of the next sludge batch of feed for the DWPF. The Advanced Design Mixer Pump (ADMP) will be used to mix the waste contents of Tank 18F prior to transfer to Tank 7F as part of this project. SRS and Pacific Northwest National Laboratory (PNNL) personnel have identified several technical issues concerning the ADMP retrieval system's capability. These technical issues are listed below.

- The estimated cleaning radius (ECR) of the ADMP may not be capable of reaching the wall of Tank $18 \mathrm{~F}$.

- The ability of the ADMP to fully suspend and efficiently remove the fast-settling solids and sludge from Tank $18 \mathrm{~F}$ is unknown.

- The effect of mixer jet elevation on mixing and solids transport within the tank is unknown.

- $\quad$ The aerosols produced by the ADMP at low operating levels may exceed Authorization Basis $(\mathrm{AB})$ guidelines for workers and the public.

As a response to these technical issues, SRS tasked PNNL to evaluate the capability of the Tank $18 \mathrm{~F}$ retrieval system to suspend and transfer the solid waste out of Tank $18 \mathrm{~F}$ and to also provide recommendations for full-scale operation of the ADMP in Tank 18F. A simulant had to be developed, based on sample data and process knowledge, to properly test the ADMP.

During the removal of the remaining contents in Tank 19F, a mound of material was discovered. Samples of the settled solids layer were collected from Tank 19F on 12/7/00. Approximately 180 grams of material was sent to Savannah River Technology Center (SRTC) for analysis $\{1,2\}$.

Upon arriving at SRTC, the sample was placed into the SRTC Shielded Cells Facility. A portion of this sample was dissolved $\{1\}$ and the remaining portion of the Tank 19F sample was used for weight percent solids measurements, settling tests, and rheological measurements $\{3\}$. Testing with non-radioactive simulants was completed by SRTC to support the radioactive characterization of the Tank 19F sample. This report presents the results obtained from the radioactive and nonradioactive simulant characterization of the Tank 19F material. 
WSRC-TR-2002-00070

Page 9 of 26

\subsection{SAMPLING AND RECEIPT OF THE RADIOACTIVE TANK 19F MOUND SAMPLE}

A short core sampler and extension pipes were connected together and a sample cup was attached at the end of the extension pipes in order to obtain a sample of the Tank 19F mound. The extension pipes were then used to force the sampler into the mound. Once the extension pipes were submerged into the material, solids and liquid in the mound entered the sample cup. The sample cup retained a sample of the mound material upon retraction of the extension pipes from the mound material. The sample cup was de-attached from the extension pipes and sent to the SRTC Shielded Cells in a "doorstop" transport package.

The "doorstop" package was unloaded upon arrival at SRTC, and the sample was placed into the Shielded Cells. The sample was opened and poured into two-labeled glass jars and weighed to obtain the mass of the sample. The sample appeared to flow easily from the original container, based on visual observation made during the pouring of the sample from the original container to the glass jars. The sample could be described as moist, dark, granular solids as shown in Figure 1. These were determined to be a form of zeolite $\{1\}$. Approximately 180 grams of Tank $19 \mathrm{~F}$ material was obtained for all of the analyses.

\section{Figure 1: “As Received” Radioactive Tank 19F Mound Sample in the Shielded Cells}

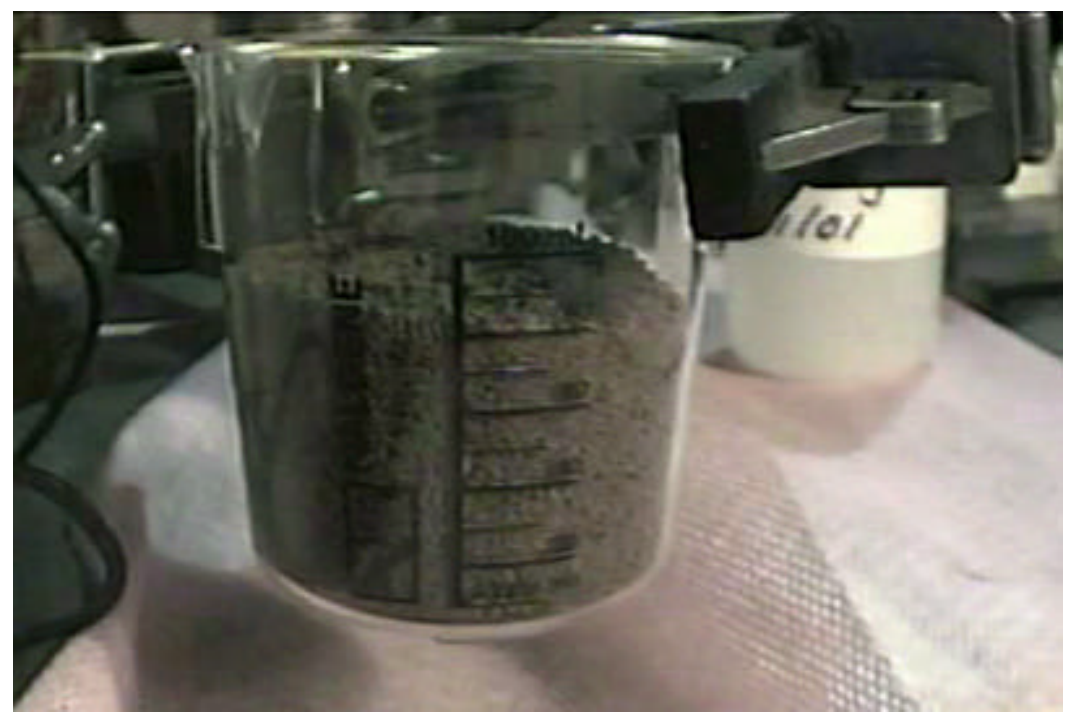

\subsection{RECEIPT OF THE NON-RADIOACTIVE SIMULANTS}

The non-radioactive simulants (to be called simulants from now on) were provided by PNNL under the direction of SRS F-Area Tank Farm - Tank closure organization. Three different simulants were provided, one containing $100 \%$ sand, one containing $100 \%$ zeolite, and the third containing a blend of sand and zeolite. The zeolite/sand mixture was considered the simulant for the Tank 19F sample. This was based on what was assumed to be in the Tank 19F sample, prior to formal analysis. SRTC personnel analyzed these samples at the TNX pilot plant facility. 
WSRC-TR-2002-00070

Page 10 of 26

\subsection{PHYSICAL \& YIELD STRESS RESULTS}

This section describes the methods and results for the weight percent total solids measurements, settling tests performed at 6,11 , and 16 weight percent total solids, and the yield stress measurements.

\subsection{Weight Percent Total Solids}

Table 1 provides a brief description of the methods used to obtain weight percent total solids for the radioactive Tank $19 \mathrm{~F}$ mound sample and the PNNL simulants.

Table 1: Weight Percent Total Solids Measurement Method

\begin{tabular}{|c|c|}
\hline $\begin{array}{c}\text { Description of the Conventional Oven } \\
\text { Method Used for the Radioactive Tank } \\
\text { 19F Sample }\end{array}$ & $\begin{array}{l}\text { Description of the Halogen Moisture } \\
\text { Analyzer Used for the PNNL Simulants }\end{array}$ \\
\hline $\begin{array}{l}\text { - Calibrated scale used for all weighing. } \\
\text { Function is verified by checking with } \\
\text { calibrated weights each day when in use } \\
\text { - Sample holder is weighed and the weight } \\
\text { recorded. } \\
\text { - Homogeneous sample is placed into holder, } \\
\text { weighed and the weight is recorded. } \\
\text { - Sample placed into oven for at least } 16 \mathrm{hrs} \text { at } \\
115^{\circ} \mathrm{C} \text {. The first weighing is recorded. } \\
\text { Sample weighed/recorded every } 8 \text { hours } \\
\text { thereafter until a consistent weight has been } \\
\text { obtained. } \\
\text { - Wt. \% total solids are calculated using } \\
\text { equation [1]. }\end{array}$ & $\begin{array}{l}\text { - Halogen weigh scale is verified using a } \\
\text { calibrated weight each day when in use. } \\
\text { - Halogen analyzer verified operable by } \\
\text { checking with salt solution of known total } \\
\text { solids. } \\
\text { - Sample paper placed into analyzer and } \\
\text { tarred. } \\
\text { - Homogeneous sample is placed onto the } \\
\text { paper, and the moisture analyzer records its } \\
\text { initial mass. } \\
\text { - Halogen moisture analyzer maintains a } \\
\text { sample chamber temperature of } 105^{\circ} \mathrm{C} \text { until } \\
\text { the change in mass/time is below a set point } \\
\text { and records the final mass. } \\
\text { - Analyzer calculates weight percent total } \\
\text { solids. }\end{array}$ \\
\hline
\end{tabular}

Equation [1] was used to calculate the weight percent total solids of the as-received radioactive Tank 19F sample and PNNL simulants. This calculation was performed and reported by the halogen moisture analyzer and manually calculated for the oven results. Duplicate samples of the radioactive Tank 19F sample and each PNNL simulant were analyzed. Table 2 presents the average values and standard deviations for these samples.

$$
w t . \%_{T S}=\frac{m_{D S}}{m_{S}} \cdot 100 \%
$$

Where: $w t . \%_{T S}=$ weight percent total solids concentration in the slurry

$m_{D S} \quad=$ mass of the dried sample (grams)

$m_{S} \quad=$ mass of the sample (grams) 
WSRC-TR-2002-00070

Page 11 of 26

Table 2: Weight Percent Total Solids of As-Received Samples

\begin{tabular}{|l|c|c|}
\cline { 2 - 3 } \multicolumn{1}{c|}{} & \multicolumn{2}{c|}{ Weight Percent Total Solids } \\
\hline Sample Name & Average & $\begin{array}{c}\text { Standard } \\
\text { Deviation }\end{array}$ \\
\hline Radioactive Tank 19F & 85.55 & \pm 0.17 \\
\hline PNNL Zeolite simulant & 62.00 & \pm 1.90 \\
\hline PNNL Sand simulant & 99.85 & \pm 0.21 \\
\hline PNNL Tank 19F simulant & 85.33 & \pm 0.63 \\
\hline
\end{tabular}

\subsection{Settling Tests}

Slurry samples were prepared at 6,11 , and 16 weight percent total solids for the radioactive Tank 19F sample and PNNL simulants. These wt. \% total solids were based on the assumed total solids concentration expected when the contents were homogeneously mixed in the process vessels. The average weight percent total solids reported in Table 2 were used with equations [2] and [3] to make 100 grams of each of these slurries. The radioactive Tank 19F slurries were prepared using inhibited water $\left(0.015 \mathrm{M} \mathrm{NaOH}\right.$ and $\left.0.015 \mathrm{M} \mathrm{NaNO}_{2}\right)$ to simulate Tank Farm operations. The PNNL simulant slurries were prepared using deionized (DI) water. Equation [2] was used to determine the mass of as-received sample required for each of the three targeted weight percent total solids. Equation [3] was used to determine the amount of inhibited or DI water required for 100 grams of total mass. Table 3 presents the masses used to prepare slurries at 6,11 , and 16 weight percent total solids for the radioactive Tank 19F sample and the PNNL simulants.

$$
\begin{aligned}
& m_{\text {solids, },}=100 \mathrm{grams} \text { Total } \cdot \frac{\mathrm{wt.} \% \mathrm{~T} . S_{\cdot_{\text {Target }}}}{100 \%} \cdot \frac{100 \%}{\mathrm{wt} . \% \text { T.S. } \cdot_{\text {avg, Table } 2}} \\
& m_{\text {Water }}=100 \mathrm{grams} \text { Total }-m_{\text {solids }, I}
\end{aligned}
$$

Where: $\quad \mathrm{m}_{\text {solids, } \mathrm{I}}=$ solids mass of the $\mathrm{I}^{\text {th }}$ sample to add for a given wt. \% T.S.Target

$$
\mathrm{m}_{\text {Water }}=\text { mass of inhibited or DI water to add to } \mathrm{m}_{\text {solids,I }}
$$

wt. $\%$ T.S.Target $=$ wt. $\%$ targets $(6,11$, and $16 \mathrm{wt} . \%$ total solids $)$

$w$ t. $\%$ T.S.avg,Table $2=$ average total solids of analyzed samples in Table 2

A settling test was performed on each sample following preparation per Table 3. Each sample had to be thoroughly mixed in order to perform a settling test. Mixing was achieved by shaking the bottles. Once the mixing stopped, any visible particles settled within 5 seconds for all the PNNL simulant slurries and within 20 seconds for the radioactive Tank $19 \mathrm{~F}$ slurries. The 20 second figure is conservative for the radioactive Tank $19 \mathrm{~F}$ slurries, since the large solids (see Figure 1), could easily be seen settling through the suspended slurry once agitation stopped. These rapid settling times held for all of the slurries in Table 3. These settling times also indicated that rheological flow curve measurements would not be possible using bench top rheometers. The only rheological parameter that could be measured was the yield stress (using a vane rotor) for these fast settling slurries. This 
WSRC-TR-2002-00070

Page 12 of 26

measurement can be made with the solids essentially settled out of the carrier fluid. Rheological characterizations of the carrier fluids were not requested, but they were presumed to be Newtonian in nature with a viscosity close to one centipoise.

Table 3: Masses Used to Make 6, 11 and 16 Weight Percent Total Solids Slurries

\begin{tabular}{|c|c|c|c|c|c|c|c|c|}
\hline & \multicolumn{3}{|c|}{ Mass (grams) of water and sample required for a total mass of 100 grams } \\
\cline { 2 - 9 } & \multicolumn{2}{|c|}{$\begin{array}{c}\text { PNNL Zeolite } \\
\text { simulant }\end{array}$} & \multicolumn{2}{c|}{$\begin{array}{c}\text { PNNL Sand } \\
\text { simulant }\end{array}$} & \multicolumn{2}{c|}{$\begin{array}{c}\text { PNN Tank 19F } \\
\text { simulant }\end{array}$} & \multicolumn{2}{c|}{$\begin{array}{c}\text { Radioactive Tank } \\
\text { 19F sample }\end{array}$} \\
\hline $\begin{array}{c}\text { Wt. \% } \\
\text { total } \\
\text { solids }\end{array}$ & DI water & Sample & DI water & Sample & DI water & Sample & $\begin{array}{c}\text { Inhibited } \\
\text { water }\end{array}$ & Sample \\
\hline 6 & 90.32 & 9.68 & 93.99 & 6.01 & 92.97 & 7.03 & 92.99 & 7.01 \\
\hline 11 & 82.26 & 17.74 & 88.98 & 11.02 & 87.11 & 12.89 & 87.15 & 12.85 \\
\hline 16 & 74.19 & 25.81 & 83.98 & 16.02 & 81.25 & 18.75 & 81.31 & 18.69 \\
\hline
\end{tabular}

Figure 2 shows pictures of the Tank 19F samples prepared at 6, 11, and 16 wt. \% total solids respectively. Figure 3 shows the height of the $16 \mathrm{wt}$. \% total solids PNNL simulant slurry settled layers relative to the FL-22 vane rotor. This indicated that higher wt. \% total solids slurries would be required to obtain proper yield stress measurements. This lack of sufficient settled solids to perform vane yield stress measurements with the $16 \mathrm{wt} . \%$ total solids was also evident with the radioactive Tank 19F prepared samples as seen in Figure 2.

Figure 2: Radioactive Tank 19F Slurries Prepared at 6, 11, and 16 Weight Percent Total Solid Slurries
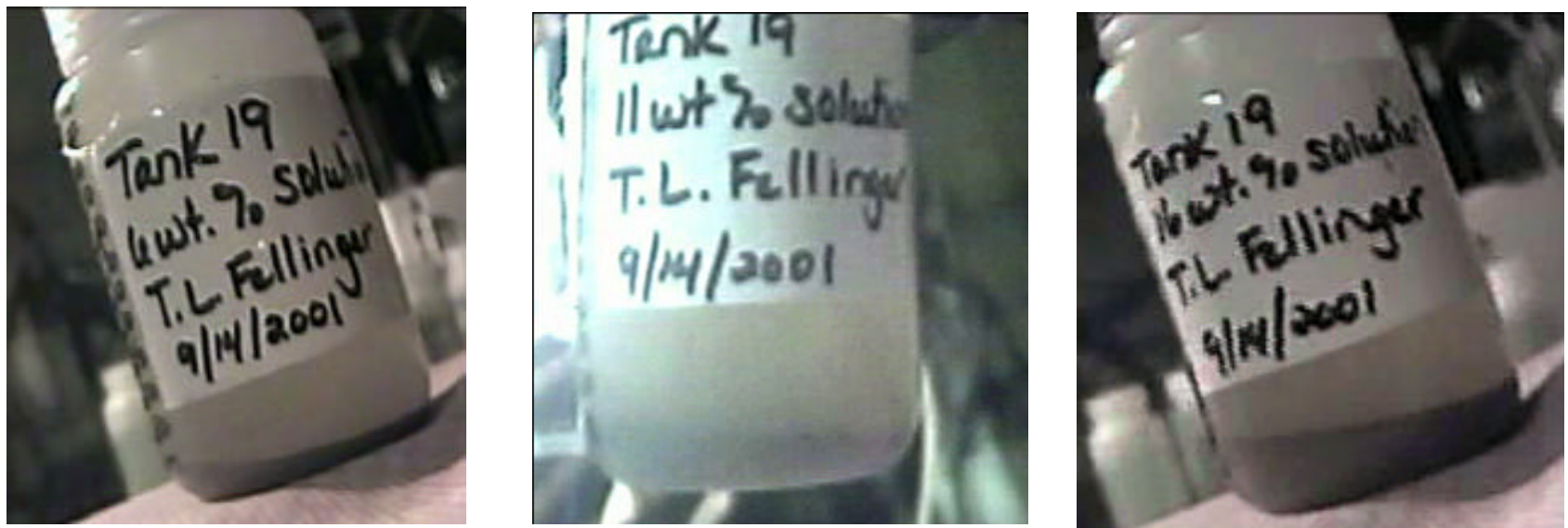
WSRC-TR-2002-00070

Page 13 of 26

Figure 3: PNNL Simulant Slurries at 16 wt. \% Total Solids Compared to the FL-22 Vane Rotor

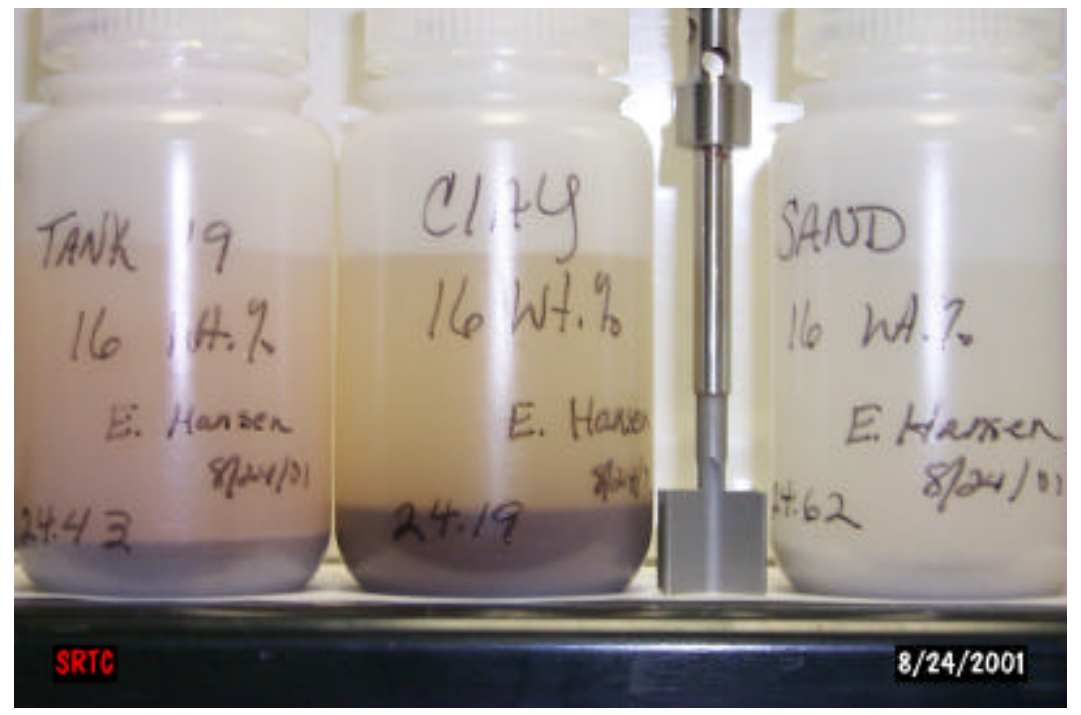

\subsection{Yield Stress Measurement}

This section describes the method, equipment, and yield stress results obtained for the radioactive Tank $19 \mathrm{~F}$ sample and the PNNL simulants.

\subsubsection{Method and Equipment to Perform Yield Stress Measurements}

The yield stresses of the radioactive Tank 19F sample and PNNL simulants were determined using a vane method $\{4,5,6\}$. This method assumes that the stress is uniformly distributed everywhere on the cylindrical surfaces (including bottom of the cylinder and the top of the cylinder for covered and uncovered conditions) created by the vane. As the vane rotates through the sample, the ideal response is a linear increase in stress (solid-like behavior), followed by a clear break from linearity (at the transition from a solid-like state to a flowing fluid). The break is typically followed by either a maximum stress that falls off to a lower steady state stress or else by a break from linearity with a leveling off to a constant stress.

A general guideline for geometric proportions has been proposed $\{4\}$ for the vane geometry when making yield stress measurements, assuming that adequate material is available. The dimensions shown in Figure 4 are recommended $\{4\}$ for obtaining satisfactory measurements, taking into consideration the vane dimensions and system boundaries.

The stress developed, when the vane is completely immersed in the sample and rotated slowly through the sample is determined by equation [4] \{4\}. A targeted rotational speed of $1.5 \mathrm{rpm}$ was used for the radioactive Tank 19F sample and $0.2 \mathrm{rpm}$ for the 
WSRC-TR-2002-00070

Page 14 of 26

PNNL simulant samples. The difference in the applied rotation speeds was due to a communication error. This difference did not impact the final results, since the nonhomogenous slurries in this study had little to no viscous component, which can be sensitive to the applied rate.

\section{Figure 4: Vane Rotor Geometric Conditions For Measurement}

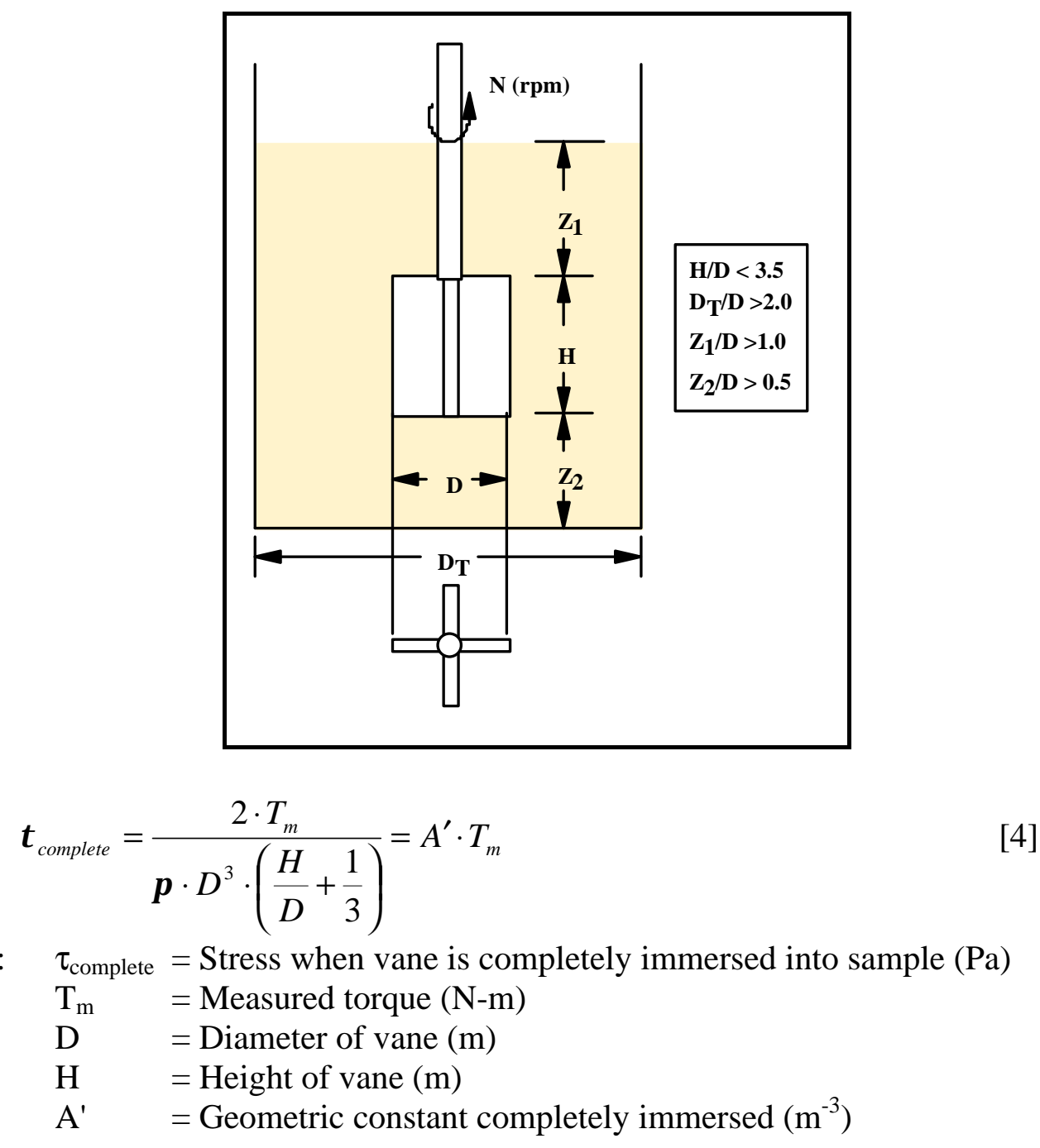

In the case where the top of the vane is flush with the top of the sample, the stress developed is given by equation [5] $\{5\}$. The difference between equation [4] and equation [5] is the $1 / 3$ and $1 / 6$ factors. The $1 / 3$ factor is the stresses at the top and bottom of the cylinder, when the vane is totally immersed into the sample. The $1 / 6$ factor is the stress at the bottom of the cylinder, when the top of the vane is flush with the top of the sample. This measurement is not typically performed, but provides a method to measure the yield stress in cases where there is insufficient sample too fully cover the vanes per Figure 4. 
WSRC-TR-2002-00070

Page 15 of 26

$$
\tau_{\text {top, uncovered }}=\frac{2 \cdot T_{m}}{\pi \cdot D^{3} \cdot\left(\frac{H}{D}+\frac{1}{6}\right)}=A^{\prime \prime} \cdot T_{m}
$$

where: $\mathrm{A}^{\prime \prime} \quad=$ Geometric constant vane flush with sample $\left(\mathrm{m}^{-3}\right)$

$\tau_{\text {top, uncovered }}=$ stress when top of vane is flush with the sample $(\mathrm{Pa})$

Yield stress was measured using one of two Haake rheometers. Both rheometers are considered Searle type measuring systems, where both the speed and torque are measured at the rotating shaft. The RS150 rheometer can be run using either the controlled rate or controlled stress modes. In the controlled rate mode the shear rate, or angular velocity, is applied and the resulting shear stress is measured. In the controlled stress mode the shear stress, or torque, is applied and the resulting shear rate is measured. Only the controlled rate mode was used for measurements made with the RS150 rheometer in this study. An FL22 vane rotor was used for measuring the stress of the PNNL simulants with the RS150. The RV30/M5 rheometer is a controlled rate rheometer. A vane rotor was provided by PNNL for measuring the stress of the radioactive Tank 19F sample. The dimensions of the vanes and cups used as well as specifications of the two rheometers are shown in Table 4. The vanes used in this study all have 4 blades.

Table 4: Vane, Cup, and Rheometer Specifications

\begin{tabular}{|c|c|c|c|}
\hline & Parameter & RV30/M5 Rheometer & RS150 Rheometer \\
\hline \multirow{2}{*}{ Vane } & D- diameter (m) & 0.008 & 0.022 \\
\hline & H- height (m) & 0.016 & 0.016 \\
\hline \multirow{2}{*}{ Cup } & $\mathrm{D}_{\mathrm{T}^{-}}$diameter $(\mathrm{m})$ & 0.042 & $\approx 0.108$ \\
\hline & Height (m) & $\approx 0.090$ & $\approx 0.070$ \\
\hline \multirow{2}{*}{\multicolumn{2}{|c|}{$\begin{array}{c}\text { Iorque Range } \\
\text { Speed Range (controlled rate) }\end{array}$}} & 0.049 to $4.9 \mathrm{~N}-\mathrm{cm}$ & 0.0005 to $150 \mathrm{mN}-\mathrm{m}$ \\
\hline & & 0.05 to $500 \mathrm{rpm}$ & 0.01 to $1100 \mathrm{rpm}$ \\
\hline
\end{tabular}

Prior to using the rheometers to measure the stress, the rheometers were functionally checked using a Newtonian oil standard. A concentric cylindrical geometry was used for the RV30/M5 rheometer while a cone and plate geometry was used for the RS150 rheometer when performing this functional check. The rheometers were considered functional, if the calculated viscosity was within $\pm 10 \%$ of the nominal value for the oil standards used. Both the RV30/M5 and RS150 rheometers passed their functional tests.

The method used by the Haake software to translate the measured torque and speed to stress and shear rate is through the use of $\mathrm{A}$ and $\mathrm{M}$ factors. The A factor is a shear stress factor, and the $\mathrm{M}$ factor is a shear rate factor. These are typically determined geometrically. The generic forms are shown as equation [6] and equation [7]. The A and M factors used in the RV30/M5 and RS150 rheometer are given in Table 5. 
WSRC-TR-2002-00070

Page 16 of 26

$$
\begin{aligned}
& \tau=A \cdot M_{d} \\
& \dot{\gamma}=M \cdot \dot{\Omega}
\end{aligned}
$$

where: $\quad \tau=$ Calculated stress $(\mathrm{Pa})$

$$
\begin{aligned}
\mathrm{M}_{\mathrm{d}} & =\text { measured torque }(\% \text { torque or } \mathrm{N}-\mathrm{m}) \\
\mathrm{A} & =\text { shear stress factor }(\mathrm{Pa} /(\% \text { torque }) \text { or } \mathrm{Pa} /(\mathrm{N}-\mathrm{m})) \\
\dot{\gamma} & =\text { calculated shear rate }\left(\mathrm{sec}^{-1}\right) \\
\dot{\Omega} & =\text { measured angular velocity }(\% \mathrm{rpm} \text { or radians } / \mathrm{sec}) \\
\mathrm{M} & =\text { shear rate factor }\left(\mathrm{sec}^{-1} /(\% \mathrm{rpm}) \text { or } \sec ^{-1} /(\mathrm{rad} / \mathrm{sec})\right)
\end{aligned}
$$

The RV30/M5 and RS150 software typically require the end user to specify a shear rate range in which the measurement will be taken. For vane measurements, the reported value is typically revolutions per minute, not shear rate, since the A factor for the vane is

\begin{tabular}{|c|c|c|c|c|}
\hline Rheometer & A factor & $\begin{array}{l}\text { Actual } \\
\text { Speed } \\
\text { (rpm)* }\end{array}$ & M Factor & $\begin{array}{c}\mathrm{K} \text { - Stress } \\
\text { Correction } \\
\text { factor** }^{* *}\end{array}$ \\
\hline RV30/M5 & $1 \mathrm{sec}^{-1} / \% \mathrm{rpm}$ & 1.5 & $1 \mathrm{~Pa} /(\%$ Torque $)$ & 281.2 \\
\hline RS150 & $\left.1 \mathrm{sec}^{-1} /(\mathrm{rad} / \mathrm{sec})\right)$ & 0.2 & $56370 \mathrm{~Pa} /(\mathrm{N}-\mathrm{m})$ & 1.19 \\
\hline
\end{tabular}
not geometrically calculated. The objective of the vane method is to control the rotational speed. The actual rotational speeds used to make the measurements using the RV30/M5 and RS150 are shown in Table 5. The calculation converting a shear rate input to rotational speed is in Appendix A.

Table 5: A, M and Stress Correction Factors for the RV30/M5 and RS150 Rheometers

The M factor for the RV30/M5 was not geometrically calculated, but was used for measurement sake, hence this calculated stress must be corrected for the given geometry. The M factor for the RS150 was calculated using equation [4] by the vendor and used in the vendor's software. Stress correction factors are required to convert the calculated stress for the case where the top of the vane is located near (or flush with) the top of the sample, which is the case for the RV30/M5 data and for some of the data taken with the RS150. These stress correction factors shown in Table 5 were calculated and shown in Appendix A. This correction factor was multiplied with the calculated stress of the vendor's software to arrive at the corrected stress as shown in equation [8].

$$
\tau_{\text {corrected }}=K_{\text {correction_factor }} \cdot \tau_{\text {calculated }}
$$


WSRC-TR-2002-00070

Page 17 of 26

\subsubsection{Yield Stress Measurement - Radioactive Tank 19F Sample}

The materials used in the settling tests were recovered and used, due to the lack of radioactive Tank 19F sample provided. Inhibited water was used to wet the samples and two vane measurements with the top of the vane approximately flush with top of the settled sample were made, see Figure 5 and Figure 6. The resulting vane measurements, in which the stresses have been corrected using equations 5 and 8, are shown in Figure 7. The initial yield stress peaks were 290 and $391 \mathrm{~Pa}$ for the measurements taken of the sample after it was allowed to just settle (van1tk19) and approximately 16 hours after being mixed (van7tk19) respectively. After the initial peak, the stress dropped off drastically for both measurements, unlike a typical vane measurement. For the measurement that was taken after allowing the material to sit overnight (Figure 6 and van7tk19 in Figure 7), a maximum stress was measured at 563Pa, which came much later and was much higher than the initial peak. No subsequent peaks exceeded the initial peak for this measurement. The subsequent peaks/valleys are not typical of vane measurements of homogenous slurries with yield stress. This pattern of peaks and valleys seems to be purely mechanical in nature. This can be partially explained by an analogy to what happens when a mixed bag of marbles are placed into a container and a vane is inserted into this matrix. As the vane rotates through the marbles, the marbles align in such a manner that they build a bridge between the walls of the container and the rotating vane. As the vane keeps rotating, the stress increases, and the bridge finally breaks. Then as the vane keeps rotating through the marbles, another bridge forms, which may or may not be as strong as the original bridge.

\section{Figure 5: Radioactive Tank 19F Sample Prior To and After the First Vane Measurement in} the Shielded Cells
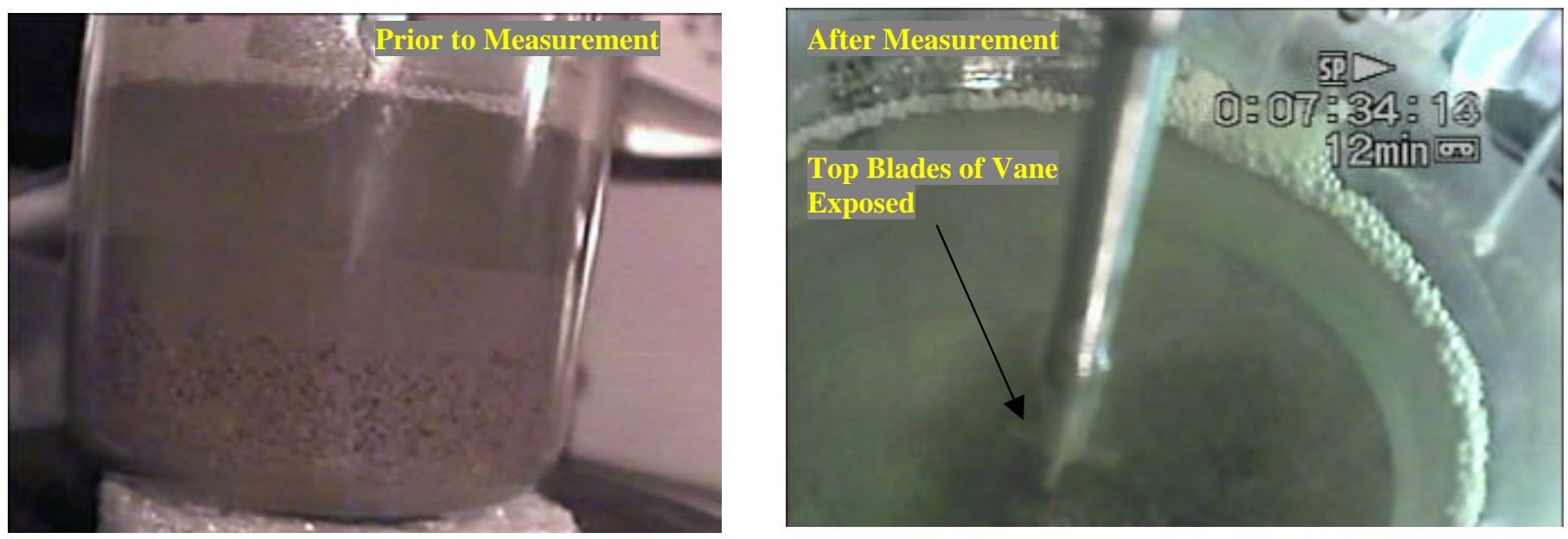

Figure 6: Radioactive Tank 19F Sample Prior To and After the Second Vane Measurement in the Shielded Cells (Next Day) 
WSRC-TR-2002-00070

Page 18 of 26
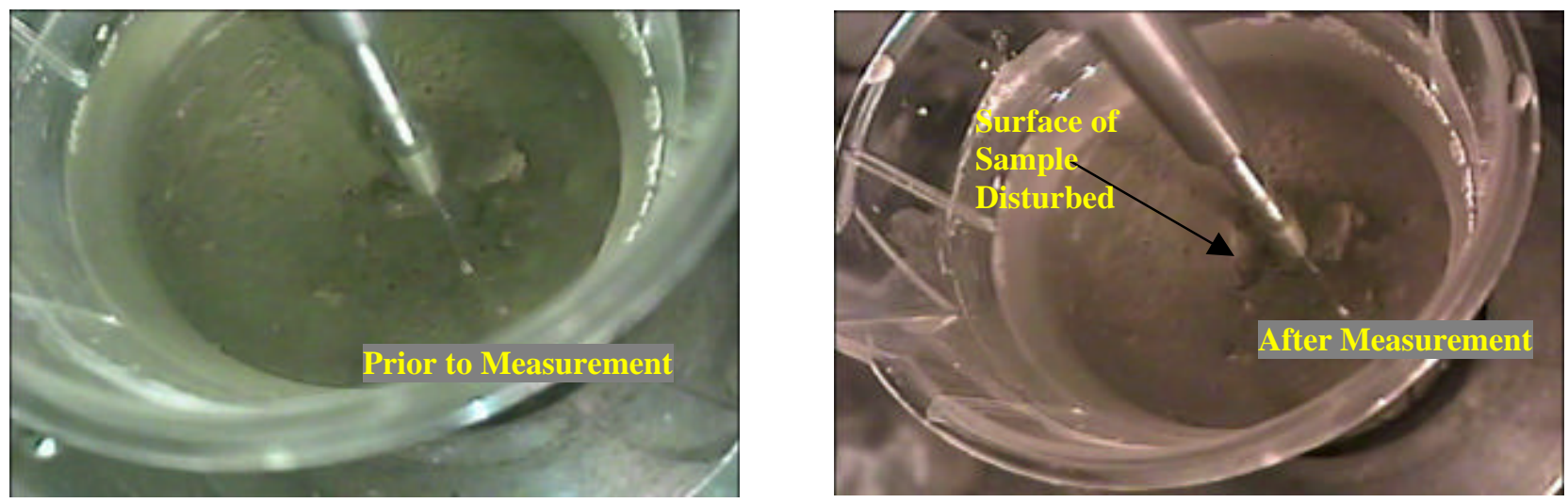

Figure 7: Vane Measurements for Radioactive Tank 19F Sample

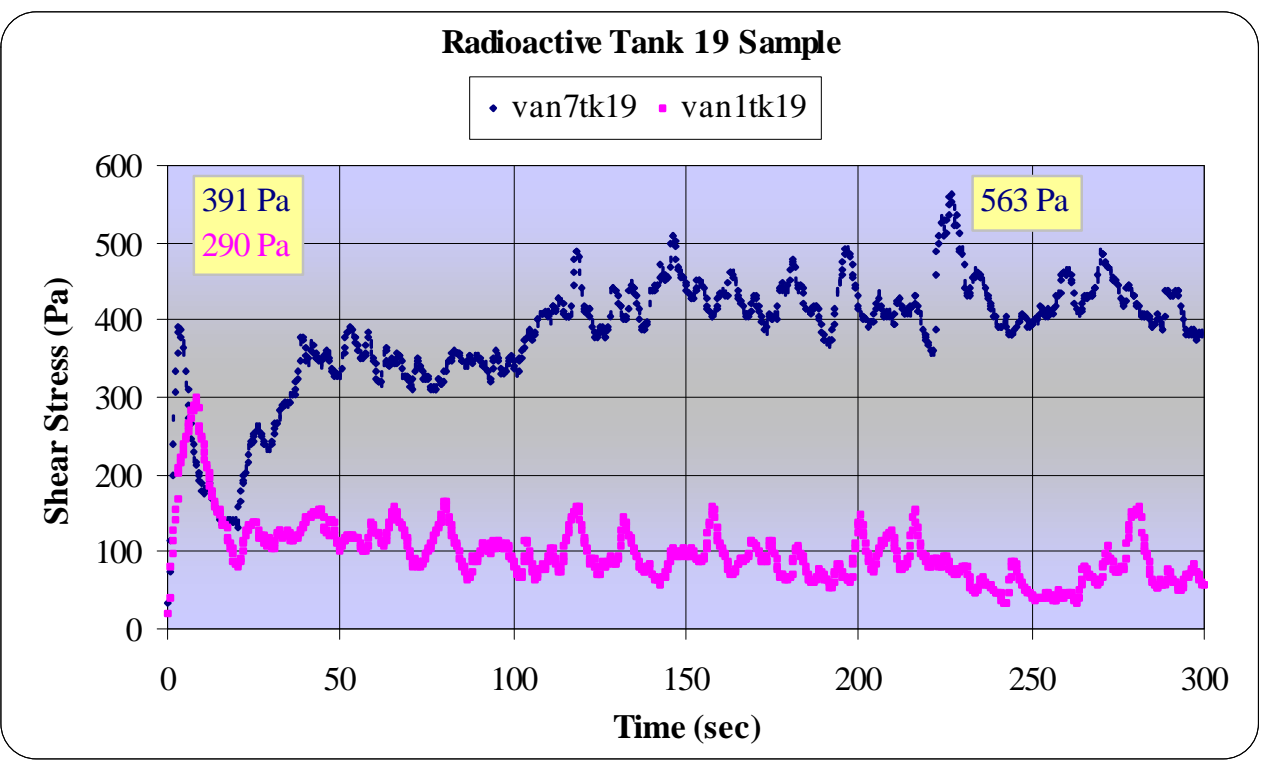

\subsubsection{Yield Stress Measurement - PNNL Simulants}

PNNL Tank 19F, sand and zeolite simulant samples were mixed in the measuring cups by adding the as-received samples and then adding water. This cycle was repeated so that all of the as-received materials added would get properly wetted. The amount of asreceived material added was based on targeting a level in the measuring cup that would have provided a clearance of one vane height below and above the vane, when the vane was installed at $16 \mathrm{~mm}$ above the bottom of the cup. The height of the sample above the vane was calculated by determining the height of the sample and subtracting $32 \mathrm{~mm}$ from the result. The actual amount of sample added was determined after the mixture was allowed to settle for 16 hours in which a clear supernate was visible. Table 6 lists the sample coverage over the vane, which indicate that we did not achieve the Z1 condition as shown in Figure 4. During the vane measurements, where the vane was 
WSRC-TR-2002-00070

Page 19 of 26

submerged into the samples, no motion was seen on the top surfaces of the samples. For this reason, equation [4] was used to determine the stress.

Table 6: PNNL Simulant Sample height above vane.

\begin{tabular}{|c|c|}
\hline Simulant & Height of sample above vane $(\mathrm{mm})$ \\
\hline Tank 19F Material & 8.4 \\
\hline Zeolite & 8.8 \\
\hline Sand & 7.2 \\
\hline
\end{tabular}

Three different yield stress measurements were made. After each measurement, the sample was mixed with a small spatula and allowed to settle for from 5 to 15 minutes before the next measurement. After the third measurement, the samples were then allowed to sit for approximately 16 hours (called Next Day) and another shear measurement was taken. Finally, a surface shear measurement was taken, where the top of the vane was approximately level with that of the sample as shown in Figure 8. In Figure 8, one can see the cross created by the 4 blades of the vane where it penetrated the sand sample, but not the top of the blades. The yield stress measurement results are shown graphically in

Figure 9, Figure 10, and Figure 11 for Tank 19F, zeolite, and sand respectively

Figure 8: Vane Top Flush with PNNL Sand Simulant

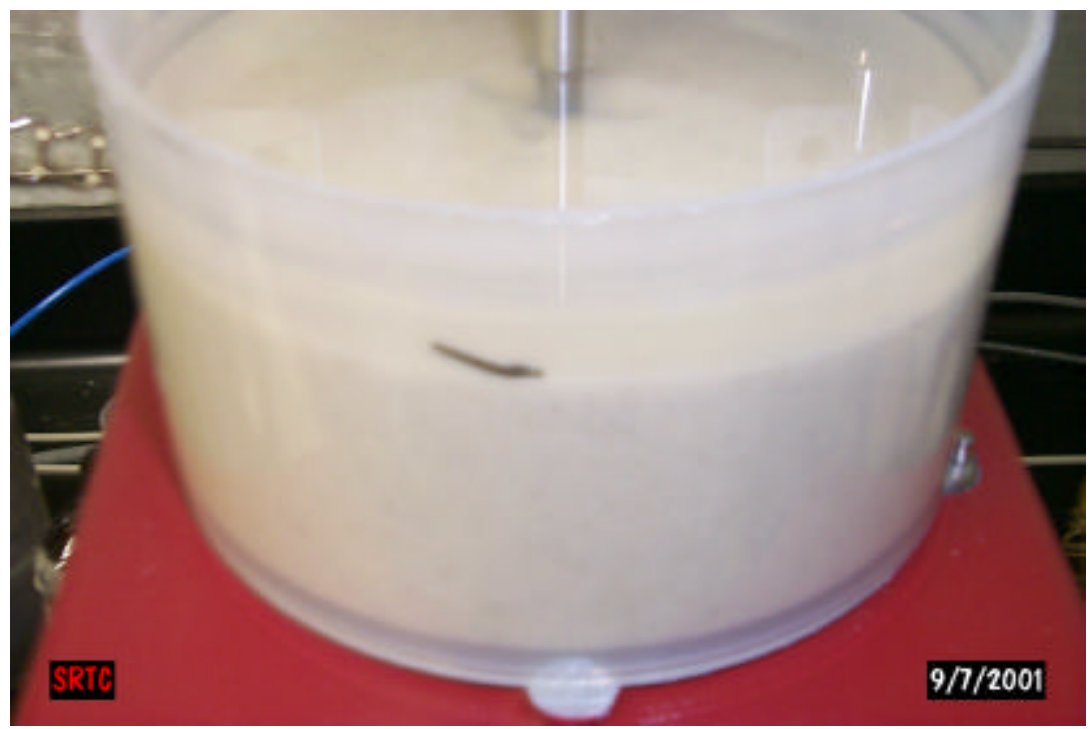

The PNNL Tank 19F simulant vane measurements shown in

Figure 9 show that the measured stress can vary greatly from the first run to the next day. The initial yield stress peaks for each stress measurement are shown in Table 7. For the measurements in which the vane was totally immersed, the results varied by almost $250 \mathrm{~Pa}$. The "next day" measurement did not produce the largest yield stress, which indicated that the Tank $19 \mathrm{~F}$ simulant particles did not excessively pack over the 
WSRC-TR-2002-00070

Page 20 of 26

16 hours of setting. The yield stress for the surface measurement was smaller than all the immersed measurements, indicating either that the amount of sample coverage could potentially effect the yield stress or that the conditions in which the measurement took place were not appropriately modeled using equation [5].

Table 7: Initial Maximum Yield Stresses of PNNL Simulants

\begin{tabular}{|c|c|c|c|c|c|}
\cline { 2 - 6 } \multicolumn{1}{c|}{} & \multicolumn{5}{c|}{ Initial Maximum Yield Stress (Pa) } \\
\hline Simulant & $1^{\text {st }}$ Run & $2^{\text {nd }}$ Run & $3^{\text {rd }}$ Run & Next Day & Surface \\
\hline Tank 19F Material & 441 & 613 & 682 & 642 & 310 \\
\hline Zeolite & 376 & 561 & 673 & 692 & 330 \\
\hline Sand & 978 & 582 & 696 & 760 & 446 \\
\hline
\end{tabular}

Figure 9: PNNL Tank 19F Simulant Vane Measurements

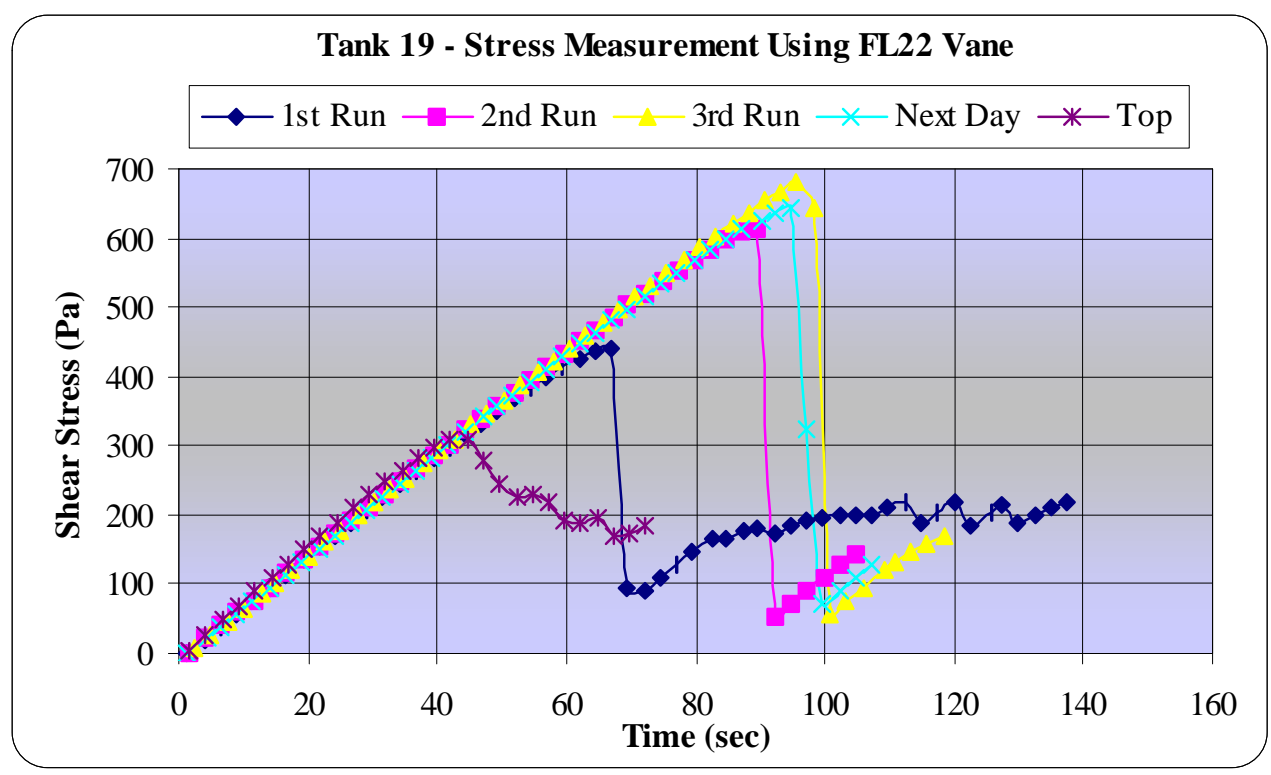

The PNNL zeolite simulant vane measurements shown in Figure 10 show that the measured stress can also vary greatly from the first run to the next day. The initial yield stress peaks for each stress measurement are shown in Table 7. For the measurements in which the vane is totally immersed, the results vary by almost $300 \mathrm{~Pa}$. The "next day" measurement was barely larger than the $3^{\text {rd }}$ measurement, indicating that the zeolite particles did not excessively pack over time. The yield stress for the surface measurement was smaller than all the immersed measurements, like that of PNNL Tank 19F simulant. 
WSRC-TR-2002-00070

Page 21 of 26

Figure 10: PNNL Zeolite Simulant Vane Measurements

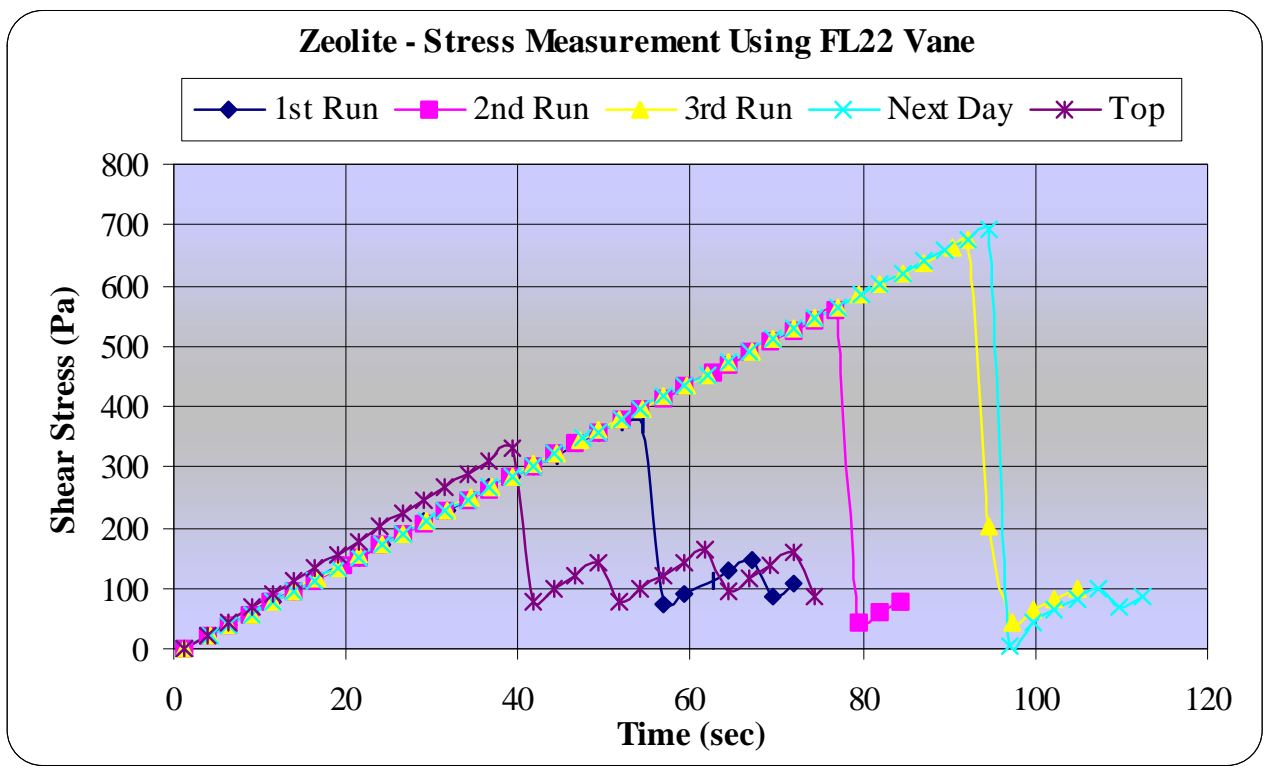

The PNNL sand simulant vane measurements shown in Figure 11 show that the measured stress can again varied greatly from the first run to the next day. The initial yield stress peaks for each stress measurement are shown in Table 7 . The results vary by almost $400 \mathrm{~Pa}$ for the measurements in which the vane was totally immersed. The "next day" measurement was much smaller than the first measurement, indicating that the sand particles did not excessively pack over time. The yield stress for the surface measurement was smaller than all the immersed measurements, like that of both the PNNL Tank 19F and zeolite simulants.

Figure 11: PNNL Sand Simulant Vane Measurements

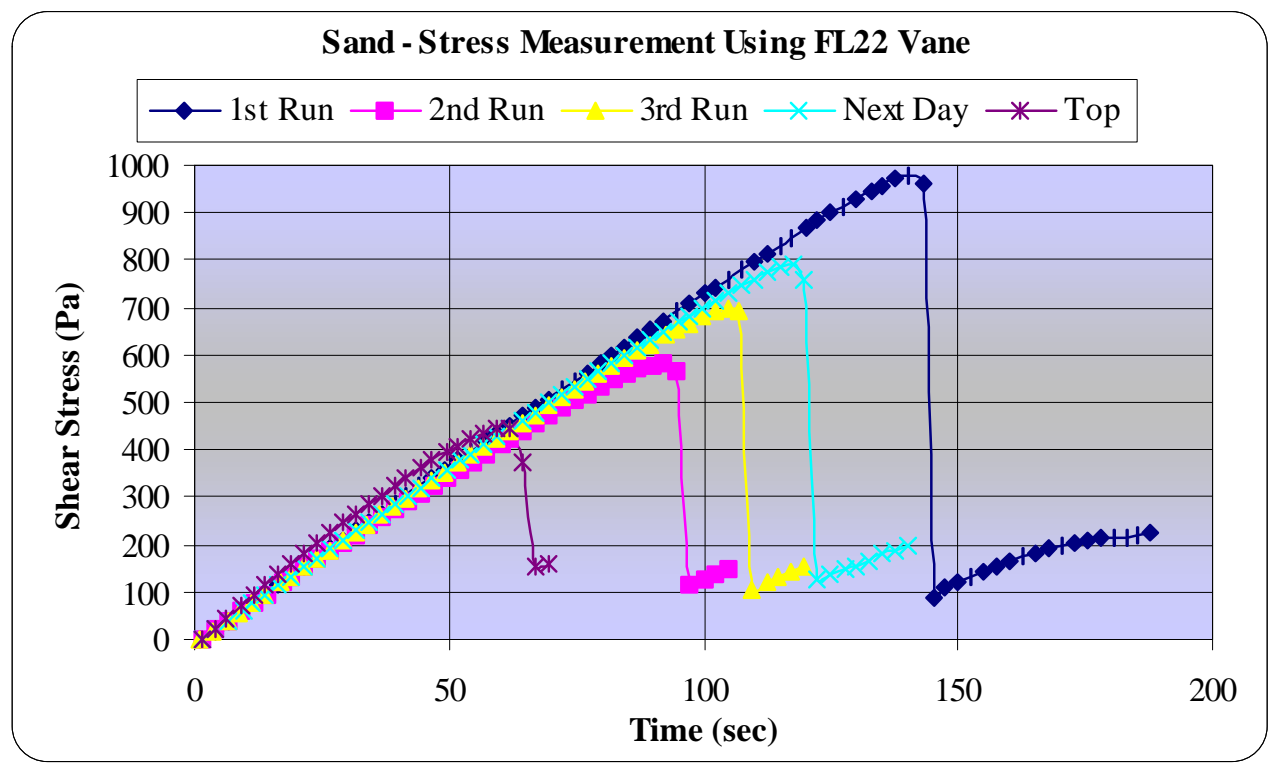


WSRC-TR-2002-00070

Page 22 of 26

Once the initial maximum yield stress was exceeded, the stress dropped drastically in all the vane measurements of the PNNL simulants. This was also seen with the actual waste. Additionally, all the yield stress measurements taken at the surface were lower than when the vane was completely immersed into the slurry, as shown in Table 7. This could indicate that the assumptions made in equation [4] and equation [5] need refinement for these types of slurries. Or, due to the amount of vane submergence, the measured yield stress varies, which supports that these slurries are not homogenous and the yield stress measurements must be used with caution. The surface yield stress measurements of the simulants compared well with that of the radioactive Tank 19F sample, which were also considered surface measurements. The yield stress curves of the simulants could not recover as quickly as that of the radioactive yield stress curve, due to the different speeds in which the radioactive and simulants were measured. The radioactive measurement speeds were 7.5 times faster than the simulant speeds. This may explain why additional peaks were not seen in the simulant measurements. The higher rotational speed used in the radioactive Tank 19F sample could have been an issue, if the slurry would have been homogenous, where the viscous effects of the slurry would have contributed to the measurement.

These measured yield stresses, for both the radioactive Tank 19F sample and PNNL simulants are not equivalent to those for homogenous slurries. If these slurries truly had yield stresses, then the settling tests performed in section 5.2 would have resulted in slurries that would have taken a very long time to settle. As was seen in section 5.2, these slurries settled very quickly and were also easily resuspended and mixed. If a homogenous slurry had the minimal reported initial yield stress of $290 \mathrm{~Pa}$ in this report, the sample would have been both a challenge to mix and a flow curve (shear stress versus shear rate) could have been obtained using a bench top rotational rheometer. Thus, these measured yield stresses have to be used with caution, when used with equations that were derived based on assumptions used in developing those equations.

\subsubsection{Density and wt. \% total solids for PNNL Simulants used for yield stress measurements}

A plastic cup was used to perform the density measurement. The volume of the cup, using DI water, was $143.5 \mathrm{~mL}$. Upon the completion of the vane measurements, the supernate was decanted from each of the simulants. The remaining solids/water was then scoped into the cup, tapped, and leveled flush with the top of the cup. The mass of the solids/water was then weighed and the tare subtracted. Table 8 lists the mass of the solids/water and the calculated density using the above volume.

Two samples of each of the decanted slurries were analyzed for weight percent total solids using the Halogen moisture analyzer. The average of two measurements are reported in Table 8. 
WSRC-TR-2002-00070

Page 23 of 26

Table 8: Density of Material Sheared by Vane Rotor

\begin{tabular}{|c|c|c|c|}
\hline PNNL simulant & $\begin{array}{c}\text { Mass of Material } \\
\text { in Cup (grams) }\end{array}$ & $\begin{array}{c}\text { Calculated Density } \\
(\mathrm{gm} / \mathrm{mL})\end{array}$ & $\begin{array}{c}\text { Wt. \% Total } \\
\text { Solids }\end{array}$ \\
\hline Tank 19F & 242.2 & 1.69 & 71.5 \\
\hline Zeolite & 207.0 & 1.44 & 53.4 \\
\hline Sand & 266.8 & 1.86 & 73.7 \\
\hline
\end{tabular}

\subsection{CONCLUSIONS}

The following conclusions were drawn from the above characterization of the radioactive Tank 19F sample and three PNNL simulants (Tank 19F, sand, and zeolite):

- Both radioactive and simulant samples settle extremely quickly.

- The radioactive sample and three simulant samples are non-homogenous slurries. They are best modeled as two-phase systems consisting of a carrier fluid with entrained solids.

- Flow curve measurements (shear stress versus shear rate) could not be performed using bench scale rotational rheometers due to the rapid settling behavior of these slurries.

- Both the radioactive and simulant vane yield stress curves (shear stress versus time) are not typical of curves for homogeneous slurries.

- The yield stresses of the radioactive and simulant slurries seem to be the similar.

- The yield stresses of the simulants seem to be subject either to how submerged the vane was into the sample or to the assumption that the equation for interpreting the vane measurement developed for a homogeneous slurry may not be applicable to a non-homogeneous slurry.

- The measured yield stresses seem to be purely mechanical in nature. No contribution due to viscous forces was noticeable.

The following issues were not addressed in this report in comparing the radioactive Tank 19F sample to the PNNL simulants:

- Effect of particle size distribution.

- Variations in particle densities.

- Critical velocity required to maintain the insoluble solids in suspension for an open system (such as a tank) and in piping systems (for transport issues).

- Blending with sludge. Does the sludge have the structure to maintain these solids in suspension?

- The applicability of the vane yield stress measurement to non-homogenous slurries.

- The applicability of equations used to determine the estimated cleaning radius with the measured yield stresses for the non-homogenous slurries. 
WSRC-TR-2002-00070

Page 24 of 26

\section{APPENDIX A: A \& M FACTORS - CALCULATED VALUES}

\section{Shear Rate Conversion between angular velocity and rotational speed}

The general equation used by Haake to determine the shear rate is given by:

$$
\dot{\gamma}=M \cdot \dot{\Omega}
$$

where:

\begin{tabular}{|l|}
\hline$\dot{A}=$ shear rate $\left(\mathrm{sec}^{-1}\right)$ \\
$\dot{\Omega}=$ angular velocity $($ radians/sec or $\%$ rpm $)$ \\
\hline $\mathrm{M}=$ shear rate factor $\left(\mathrm{sec}^{-1} /(\mathrm{rad} / \mathrm{sec})\right.$ or $\left.\mathrm{sec}^{-1} /(\% \mathrm{rpm})\right)$ \\
\hline
\end{tabular}

The input for theRV30/M5 and RS150 rheometers is to specify a shear rate, which has units of $\mathrm{sec}^{-1}$. For the RS150 and RV30/M5 rheometers, it is a one-to-one relationship between the shear rate and angular speed, since $\mathrm{M}=1 \mathrm{sec}^{-1} /(\mathrm{rad} / \mathrm{sec})$ and $1 \mathrm{sec}^{-1} /(\% \mathrm{RPM})$ respectively.

Typically, when using the vane to obtain stress measurements, a rotational speed (rpm) is specified, which provides a common basis.

\section{Calculation for RS150}

The angular speed ( $\mathrm{rad} / \mathrm{sec})$ is calculated using the rotational speed by:

$$
\dot{\Omega}=\frac{2 \pi}{60} \cdot n
$$

where: $\mathrm{n}=$ rotational speed $(\mathrm{rpm})$

Substituting [A-2] into [A-1], and for $\mathrm{M}=1$ $\sec ^{-1} /(\mathrm{rad} / \mathrm{sec})$, and solving for $\gamma$ yields,

$$
\dot{\gamma}=\frac{2 \pi}{60} \cdot n
$$

To obtain a rotational speed of $0.2 \mathrm{rpm}$, the shear rate used:

$\dot{\gamma}_{0.2 \mathrm{rpm}}=\frac{2 \pi}{60} \cdot 0.2 \approx 0.021 \frac{1}{\mathrm{sec}} \approx 0.02 \frac{1}{\mathrm{sec}}$

This shear rate was specified during the measurement.

\section{Calculation for RV30/M5}

The angular speed is calculated by:

$$
\dot{\Omega}=\% r p m=\frac{n}{n_{\max }} \cdot 100 \%
$$

where: $\mathrm{n}_{\max }=$ maximum rotational speed

$$
=500 \mathrm{rpm}
$$

Substituting [A-4] into [A-1], and for $\mathrm{M}=1$ $\mathrm{sec}^{-1} /(\% \mathrm{rpm})$ and solving for $\mathrm{n}$ yields,

$$
n=\frac{n_{\max }}{100 \%} \cdot \dot{\gamma}
$$

A shear rate of $0.3 \mathrm{sec}^{-1}$ was used, thus the rotation speed was:

$$
n=\frac{500 \mathrm{rpm}}{100 \%} \cdot 0.3=1.5 \mathrm{rpm}
$$


WSRC-TR-2002-00070

Page 25 of 26

\section{Shear Stress Correction Factors}

The general equation used by Haake to determine the shear rate is given by:

$$
\tau=M_{d} \cdot A
$$

where:

\begin{aligned} &$\tau=$ measured stress $(\mathrm{Pa}) \\ &$\hline $\mathrm{M}_{\mathrm{d}}=$ measured torque $(\mathrm{N}-\mathrm{m}$ or $\%$ torque $) \\ & \mathrm{A}=$ shear stress factor $(\mathrm{Pa} /(\mathrm{N}-\mathrm{m})$ or $\mathrm{Pa} /(\%$ torque $)) \\ &$\hline\end{aligned}

The output for the RV30/M5 and RS150 rheometers for the shear stress is Pa, but the $\mathrm{M}_{\mathrm{d}}$ factors are different. For the RS150 $\mathrm{M}_{\mathrm{d}}=56,370 \mathrm{~Pa} /(\mathrm{N}-\mathrm{m})$ and for the RV30/M5 $\mathrm{M}_{\mathrm{d}}=1 \mathrm{~Pa} /(\%$ torque).

A ratio will be used to correct the measured stress data for the measuring geometry where the top of the vane is located near the top of the sample, specifically equation [5].

\section{Calculation for RS150}

Calculate A' shown in equation [4] and using the data in Table 4:

$$
\begin{aligned}
A^{\prime} & =\frac{2}{\pi \cdot D^{3} \cdot\left(\frac{H}{D}+\frac{1}{3}\right)} \\
& =\frac{2}{\pi \cdot(0.022 m)^{3}\left(\frac{0.016 m}{0.022 m}+\frac{1}{3}\right)}=56,371 \mathrm{~m}^{-3}
\end{aligned}
$$

Note that this is essentially $\mathrm{M}_{\mathrm{d}}$ for the RS150. Calculate A" shown in equation [5] and using the date in Table 4.

$$
\begin{aligned}
A^{\prime \prime} & =\frac{2}{\pi \cdot D^{3} \cdot\left(\frac{H}{D}+\frac{1}{6}\right)} \\
& =\frac{2}{\pi \cdot(0.022 m)^{3}\left(\frac{0.016 m}{0.022 m}+\frac{1}{6}\right)}=66,881 \mathrm{~m}^{-3}
\end{aligned}
$$

Since the measured torque will be the same, equating equations [5] and [A-6] yields:

$$
\tau_{\text {top,uncovered }}=\frac{A^{\prime \prime} \cdot \tau}{A^{\prime}}=\frac{66,881}{56,371} \tau=1.19 \tau=K \tau
$$

\section{Calculation for RV30/M5}

Calculate A" shown in equation [5] and using the date in Table 4.

$$
A^{\prime \prime}=\frac{2}{\pi \cdot(0.008 m)^{3}\left(\frac{0.016 m}{0.008 m}+\frac{1}{6}\right)}=573,876 m^{-3}
$$

Calculate $\mathrm{A}$ for this case in $\mathrm{Pa} /(\%$ torque $)$ as shown in equation [A-6].

$$
\begin{aligned}
A_{\text {uncov } 30} & =A^{\prime \prime} \cdot \frac{M_{d, M A X}}{100 \%} \\
& =573,876 \mathrm{~m}^{-3} \cdot \frac{4.9 \mathrm{~N} \cdot \mathrm{cm}}{100 \%} \cdot \frac{\mathrm{m}}{100 \mathrm{~cm}} \\
& =281.2 \frac{\mathrm{Pa}}{\% \text { torque }}
\end{aligned}
$$

Since the measured torque will be the same, equation equations [5] and [A-6] yields:

$\tau_{\text {top, uncovered }}=\frac{A_{\text {uncov } 30} \cdot \tau}{A^{\prime \prime}}=\frac{281.2}{1} \tau=281.2 \tau=K \tau$ 
WSRC-TR-2002-00070

Page 26 of 26

\section{REFERENCES}

${ }^{1}$ R. F.Swingle, N. E. Bibler, and A. A. Ekechukwu, Data Report: Tank 19F NE Riser Zeolite Mound Sample Analysis, WSRC-RP-2001-00410, April 17, 2001.

${ }^{2}$ R. F. Swingle, Task Technical, Quality Assurance, and Characterization Plan for the Tank 19F Tank Closure Samples, WSRC-RP-2000-00799, Revision 0, October 2, 2000.

${ }^{3}$ B Adkin, Tank 18 Rheology Analysis to Quantify Effective Cleaning Radius, HLE-TTR-2001038, Revision 2, August 16, 2001.

${ }^{4}$ N. Q. Dzuy and D. V. Boger, Direct Yield Stress Measurements Using the Vane Method, Journal of Rheology, 29 (3), 335-347, 1985.

${ }^{5}$ A. S. Yoshimura and R. K. Prud'homme, A comparison of Techniques for Measuring Yield Stresses, Journal of Rheology, 31 (8), 600-710, 1987.

${ }^{6}$ ASTM D4648-00, Standard Test Method for Laboratory Miniature Vane Shear Test for Saturated Fine Grained Clayey Soil. 